\title{
Literature Review Penilaian Tingkat Kepuasan Layanan Produk/Jasa dengan Metode Service Quality Model
}

\author{
I.P.S. Almantara ${ }^{1}$, M. Sudarma ${ }^{2}$ I.B.A. Swamardika ${ }^{3}$ \\ [Submission: 11-04-2021, Accepted: 27-05-2021]
}

\begin{abstract}
Product / service satisfaction is one of several factors that can influence a company. Satisfaction is something that can be measured to improve and achieve goals in a company /government institution. The level of satisfaction can be measured by utilizing several methods, including Service Quality. Service Quality can show the difference between the customer's expectations of the company and the services received by the customer and the difference between the expectations and the services received can be seen the level of satisfaction provided by the customer. This study aims to determine the application of the Service Quality method in measuring the level of product/service satisfaction at companies or government institutions with the concept of literature review. The results of the literature review show that the application of the Service Quality method is more widely used in private companies than government institutions. The results also show that product / service service satisfaction is better at government institutions compared to private companies. This is shown in one of the literature which resulted in the achievement of very good levels of satisfaction with service quality in government institutions.
\end{abstract}

Keywords - Products, Service Quality Model, Service Satisfaction Level, Services.

Intisari - Kepuasan layanan produk/jasa merupakan satu diantara beberapa faktor yang dapat memberikan pengaruh pada sebuah perusahaan. Kepuasan adalah hal yang dapat diukur untuk meningkatkan dan mencapai tujuan dalam suatu perusahaan/institusi pemerintah. Tingkat kepuasan bisa diukur dengan memanfaatkan beberapa metode, diantaranya adalah Service Quality. Service Quality dapat menunjukan selisih antara harapan pelanggan terhadap perusahaan dengan layanan yang diterima oleh pelanggan dan dari selisih antara harapan dengan layanan yang diterima tersebut dapat dilihat tingkat kepuasan yang diberikan oleh pelanggan. Penelitian ini bertujuan untuk mengetahui penerapan dari metode Service Quality dalam mengukur tingkat kepuasan produk/jasa pada perusahaan atau institusi pemerintahan dengan konsep literature review. Hasil dari literature review menunjukan dari penerapan metode Service Quality lebih banyak digunakan pada perusahaan swasta dibandingkan dengan institusi pemerintahan. Hasil juga menunjukan bahwa kepuasan layanan produk/jasa lebih baik pada institusi pemerintah dibandingkan dengan perusahaan swasta. Hal tersebut ditunjukan pada salah satu literatur yang menghasilkan capaian tingkat kepuasan yang sangat baik pada kualitas layanan di institusi pemerintah.

${ }^{1}$ Mahasiswa, Magister Teknik Elektro Universitas Udayana, Gedung Pascasarjana Universitas Udayana Jl. PB Sudirman Denpasar-Bali, Kode Pos: 80232; (telp/fax: 0361-239599; e-mail: sugik.almantara@gmail.com)

2, 3 Dosen, Magister Teknik Elektro Universitas Udayana, Gedung Pascasarjana Universitas Udayana Jl. PB Sudirman Denpasar-Bali, Kode Pos: 80232; (tlp/fax: 0361-239599; e-mail: ${ }^{2}$ msudarma@unud.ac.id,3gusalit@unud.ac.id)
Kata Kunci - Jasa, Model Kualitas Layanan, Produk, Tingkat Kepuasan Layanan.

\section{Pendahuluan}

Setiap perusahaan/institusi pemerintah tentunya ingin melakukan layanan yang optimal dalam melayani pelanggan agar puas dengan layanan yang didapat [1]. Layanan yang diberikan dapat berupa layanan produk atau layanan jasa [2]. Layanan yang diberikan kepada pelanggan baik dalam bentuk produk atau jasa menjadi salah satu faktor penting yang menentukan tingkat kepuasan pelanggan. Kepuasan adalah sesuatu yang dapat diukur untuk meningkatkan dan mencapai tujuan dalam suatu perusahaan atau institusi pemerintah. Apabila layanan yang diberikan perusahaan atau institusi pemerintah kepada pelanggan memuaskan, maka pelanggan mendapatkan layanan yang sama atau melebihi dari harapan pelanggan terhadap layanan yang telah diberikan dan sebaliknya jika layanan yang diberikan kepada pelanggan kurang memuaskan maka pelanggan mendapatkan layanan yang masih dibawah harapan pelanggan terhadap layanan yang didapatkan.

Tingkat kepuasan pada sebuah layanan dapat diukur dengan menggunakan beberapa metode, diantaranya adalah Service Quality, Customer Satisfaction Index (CSI), metode Kano dan Importance Performance Analysis (IPA). Service Quality mengukur sebuah kepuasan layanan dengan cara membandingkan antara harapan pelanggan dengan layanan diterima oleh pelanggan. CSI melakukan pengukuran secara menyeluruh pada tingkat kepuasan berdasarkan tingkat kepentingan dari seluruh atribut yang diukur. Metode Kano mengukur kepuasan berdasarkan prioritas dari kebutuhan pelanggan dan mengelompokan faktor-faktor yang mempengaruhi dari produk/jasa. Metode IPA melakukan pengukuran dengan mengidentifikasi faktor-faktor yang mempengaruhi layanan produk/jasa berdasarkan kesesuaian harapan yang diberikan oleh pelanggan.

Pengukuran tingkat kepuasan dengan menggunakan metode Service Quality telah banyak digunakan oleh peneliti di Indonesia baik dalam pengukuran kepuasan layanan dan pengukuran kepuasan pelanggan. Pengukuran tingkat kepuasan menjadi penting untuk dilakukan agar dapat mengetahui harapan pelanggan kepada institusi pemerintah/perusahaan dan mengukur kualitas layanan atau produk pada institusi pemerintah/perusahaan.

Tujuan dari penelitian ini adalah untuk mengetahui penerapan dari metode Service Quality dalam mengukur tingkat kepuasan layanan produk/jasa terhadap suatu perusahaan atau institusi pemerintah agar nantinya peneliti dapat menjadikan referensi pada penelitian selanjutnya dalam mengukur tingkat kepuasan layanan baik pada layanan di institusi pemerintah atau perusahaan. 


\section{TinjaUAN PUSTAKA}

\section{A. SERVICE QUALITY MODEL}

Service Quality dikembangkan oleh Parasuraman sejak tahun 1988. Servqual dapat melihat perbedaan antara ekspektasi pelanggan tentang sebuah layanan dan pandangan pelanggan tentang layanan yang diberikan. Parasuraman, dkk mengkategorikan lima dimensi sebagai acuan suatu kualitas layanan diantaranya; fakta nyata (tangible), keterampilan (reability), daya tanggap (responsiveness), jaminan (assurance), dan empati (emphaty). Selain dikenal dengan istilah service quality, metode ini juga dikenal dengan istilah gap analysis model. Penilaian sebuah layanan pada servqual didasarkan pada atribut-atribut yang didesain dalam menilai harapan dan kesan pelanggan. Dimensi yang terdapat pada servqual yakni:

1. Fakta nyata (tangible) meliputi fasilitas, perlengkapan dan penampilan dari karyawan. kemampuan untuk memberikan pelayanan yang dijanjikan secara akurat dan handal.

2. Keterampilan (reliability) meliputi keahlian dalam melayani pelanggan dengan baik dan profesional.

3. Daya tanggap (Responsiveness) meliputi kesanggupan dalam memberikan bantuan dan solusi kepada pelanggan.

4. Jaminan (Assurance) meliputi perilaku yang sopan dan memiliki pengetahuan luas agar dapat meyakinkan pelanggan.

5. Empati (Empathy) meliputi perhatian secara pribadi atau individual kepada pelanggan.

\section{BAHAN DAN METODE}

Data yang digunakan pada penelitian ini merujuk pada penelitian-penelitian yang telah dilakukan yang didapat dari mesin pencarian Google Schoolar, Neliti, dan Researchgate. Skematik Penelitian dapat dilihat pada Gambar 1.

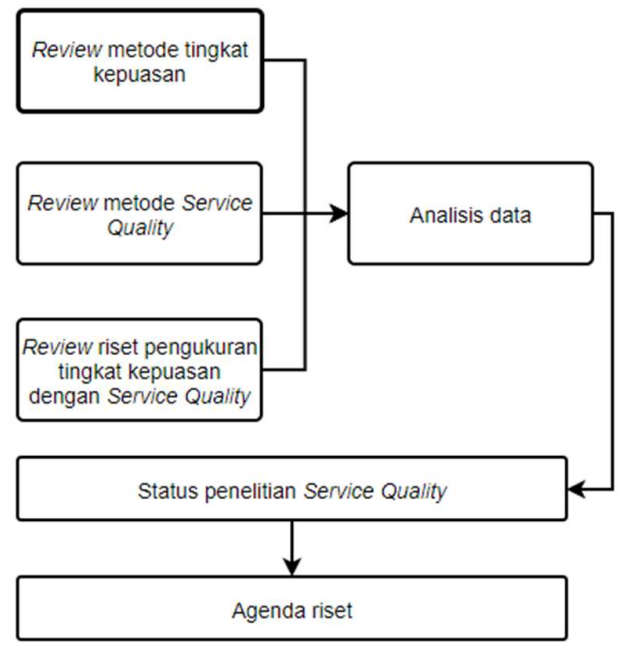

Gambar 1: Skematik Penelitian

Skematik penelitian ini menjadi pedoman dalam melakukan penelitan ini yang diawali dengan melakukan review terhadap metode tingkat kepuasan yang telah digunakan untuk menilai kualitas layanan atau produk dari sebuah perusahaan/institusi pemerintah. Tahap kedua melakukan review pada salah satu metode pengukuran layanan yakni Service Quality yang akan difokuskan pada penelitian ini dan melakukan review terhadap penelitian-penelitian mengenai Service Quality yang sudah diterapkan oleh para peneliti. Ketiga tahap tersebut kemudian dianalisis untuk mendapatkan permasalahan atau solusi yang sudah diterapkan pada sebuah sistem atau layanan jasa. Dari hasil analisis kemudian dapat dikumpulkan dan memetakan dimensi yang terdapat pada Service Quality. Pemetaan dimensi Service Quality dilakukan untuk mengidentifikasi dimensi yang memiliki pengaruh besar pada tingkat kepuasan terhadap sebuah layanan atau produk dan dimensi yang paling sering diabaikan dalam sebuah layanan atau produk. Tahap terakhir adalah agenda riset dari status penelitian yang dianalisa terkait penelitian yang menggunakan metode Service Quality yang dapat memunculkan penelitian baru atau rencana riset yang akan dilakukan berikutnya menggunakan metode Service Quality pada sistem pengadaan barang/jasa melalui eCatalogue.

\section{HASIL DAN PEMBAHASAN}

Peninjauan terhadap SQM dilakukan dengan mengetikkan kata kunci sebagai berikut: metode service quality model "servqual". Mesin pencari/pengindeks yang digunakan adalah: Google Scholar, Neliti, dan Researchgate yang memperoleh 30 buah paper yg berhubungan dengan SQM terhadap obyek penelitian di Indonesia.

A. Penelitian SQM di Indonesia

Penelitian yang dilakukan oleh Jazuli mengukur Kualitas Pelayanan dengan Service Quality dan Importance Performance Analysis di sebuah perusahan swasta. Penelitian ini fokus pada kualitas jasa yang masih menerima komplain sebanyak 4\%-7\% dari pelanggan. Pengumpulan data dilakukan dengan menggunakan kuesioner sesuai dengan dimensi dari Service Quality yang menentukan kualitas atribut layanan pada perusahaan. Hasil penelitian ini menunjukkan terdapat 3 atribut masalah yakni kesenjangan antara persepsi dan harapan konsumen yang menunjukan nilai gap atribut negatif sedangkan hasil kualitas pelayanan memperoleh hasil yang positif serta pelayanan dengan kualitas ideal [3].

Penelitian oleh Kartika, membahas kualitas pendidikan yang optimal dan sesuai dengan harapan mahasiswa dengan mengukur tingkat kepuasan terhadap kualitas layanan pendidikan dengan menggunakan metode fuzzy-servqual. Pengumpulan data dilakukan dengan menyusun kuesioner berdasarkan dimensi Service Quality berdasarkan faktor kriteria yang akan dianalisis. Hasil kuesioner setelah itu direkapitulasi berdasarkan masing-masing faktor dimensi dan kriteria yang selanjutnya uji validitas dan reabilitas data kuesioner. Tahap selanjutnya adalah menentukan fuzzy set, kemudian melakukan proses fuzzyfikasi dan terakhir melakukan proses defuzzyfikasi untuk mendapatkan nilai dari masing-masing atribut. Setelah melakukan pengolahan data menggunakan fuzzy servqual, langkah selanjutnya adalah menghitung nilai kesenjangan dengan menggunakan metode Service Quality. Hasil dari penelitian tersebut memperoleh nilai gap negatif terbesar pada atribut kenyamanan, kebersihan dan 
ketersediaan lahan parkir yang menyimpulkan bahwa layanan yang diterima oleh mahasiswa tidak sesuai dengan harapan mahasiswa [4].

Penelitian selanjutnya oleh Anwar, mengukur kepuasan sebuah sistem informasi dengan metode End User Computing Satisfaction (EUCS). Penelitian ini membahas tentang analisis tingkat kepuasan pengguna aplikasi pencatatan dan penagihan biaya pada pelanggan Perusahaan Daerah Air Minum Kota Padang. Penelitian ini memakai variabel independen (konten, akurasi, format, mudah digunakan dan tepat waktu) dan dependen (kepuasan pengguna) dengan metode pengumpulan data menggunakan kuesioner dengan responden karyawan PDAM kota Padang. Teknik pengambiulan menggunakan proporsional stratified random sampling yakni pengambilan secara acak dan berkelompok secara proporsional dari anggota populasi yang selanjutnya menggunakan rumus Slovin untuk menentukan jumlah sampel. Kuesioner sebagai instrumen dalam penelitian tersebut menggunakan skala likert lima poin, yang selanjutnya melewati tahap uji validitas dengan menggunakan Pearson Product Moment dan selanjutnya melakukan analisis regresi liner berganda yang bertujuan untuk menguji pengaruh variabel antara variabel bebas dengan variabel terikat. Metode EUCS yang digunakan memiliki hasil yang baik berdasarkan hasil tanggapan yang termasuk dalam kategori baik sekali sehingga sistem informasi tersebut sangat membantu untuk meningkatkan kinerja karyawan lebih efektif [5].

Penelitian selanjutnya yang dilakukan oleh Harto, menganalisis kepuasan pelanggan menggunakan fuzzy servqual untuk meningkatkan kualitas layanan. Mengukur kepuasan pelanggan dengan metode Service Quality yang membandingkan antara persepsi dan harapan pelanggan dan menggunakan pendekatan Fuzzy ServQual. Pengumpulan data menggunakan kuesioner berdasarkan lima dimensi Service Quality dan pengisian kuesioner menggunakan skala likert lima poin. Hasil kuesioner yang didapatkan kemudian diolah dengan metode Service Quality yang mencari kesenjangan antar kriteria dimensi Service Quality. Pengolahan data kuesioner juga diintegrasikan dengan teknik fuzzyfikasi dengan metode mamdani agar hasil dari perhitungan Service Quality menjadi lebih akurat. Hasil dari penelitian tersebut bahwa rata-rata penilaian pelanggan terhadap tingkat kualitas pelayanan bengkel adalah sedang dengan dua dimensi yang memiliki nilai rendah yakni reliability dan responsiveness [6].

Penelitian oleh Rahman, menganalisis kepuasan pelanggan pada pekerjaan reparasi kapal dengan metode Quality Function Deployment (QFD). Penelitian ini ditujukan untuk menganalisis tingkat kepuasan pelanggan atas kinerja jasa reparasi. Metode yang digunakan pada penelitian tersebut adalah Service Quality untuk menentukan tingkat kepuasan terhadap kinerja jasa dan QFD untuk mengkonversi tanggapan pelanggan secara langsung terhadap spesifikasi teknis dari jasa dan menentukan target ke depan dari sebuah perusahaan. Metode pengumpulan data yang digunakan adalah kuesioner yang telah mengidentifikasi keinginan pelanggan yang dilanjutkan dengan pengujian validasi dan reliabilitas. Dari hasil uji validitas dan reabilitas didapatkan hasil yang valid dan dilanjutkan pada proses perhitungan nilai kesenjangan berdasarkan atribut yang telah ditetapkan dengan Service Quality. Hasil perhitungan dengan menggunakan Service Quality didapatkan nilai negatif pada seluruh atribut dan dapat dikatakan pelanggan belum puas terhadap layanan jasa yang diberikan serta untuk dapat mengetahui atribut yang diproritaskan selanjutnya penelitian tersebut juga menggunakan diagram kartesius dan matriks House of Quality. Berdasarkan hasil matriks HoQ didapatkan urutan prioritas atribut yang harus segera ditingkatkan lagi agar mendapatkan kepuasan pelanggan yang sesuai dengan harapan. Hasil yang dicapai pada penelitian tersebut adalah belum mencapai pada harapan pelanggan dan perlu melakukan peningkatan kualitas pekerjaan reparasi kapal [7].

Penelitian selanjutnya oleh Wulandari, mengukur tingkat kepuasan pelayanan e-procurement menggunakan Service Quality Model di Kabupaten Sidoarjo. Penelitian ini bertujuan untuk melihat distribusi kepuasan pengguna berdasarkan lima dimensi kualitas pelayanan yaitu tangible, reliability, responsiveness, assurance dan emphaty dengan dua variabel harapan dan pernyataan agar dapat mengetahui faktor yang dapat menghambat proses tender. Kelima dimensi tersebut dimasukan pada kuesioner harapan pelanggan dan layanan yang diterima dengan menggunakan skala likert lima poin. Pengolahan data pada hasil kuesioner dilakukan uji validitas dengan menggunakan korelasi Pearson dan uji reabilitas dengan koefisien Cronbach's alpha. Data yang valid selanjutnya akan dihitung menggunakan Service Quality untuk mengetahui kesenjangan antara kenyataan dan harapan responden/pelanggan baik secara internal dan eksternal. Hasil penilaian eksternal tingkat kepuasan pelayanan pengadaan dengan nilai tertinggi terdapat pada dimensi empati (emphaty) dan yang terendah terdapat pada dimensi bukti nyata aspek kelengkapan proses pratender elektronik. Penilaian internal yang menghasilkan pelayanan terbaik yang sudah diberikan adalah pendampingan terhadap OPD pada tahap perencanaan tender sedangkan pelayanan dengan skor terendah adalah dalam hal mengutamakan kepentingan pengguna [8].

Penelitian selanjutnya oleh Shofa, membuat aplikasi pengukuran kepuasan mahasiswa pada sarpras di sebuah laboratorium dan mengukur tingkat kepuasan mahasiswa dan merancang aplikasi yang berbasis web. Perancangan aplikasi dilakukan dengan metode Waterfall. Hasil yang diperoleh dari penelitian tersebut adalah melakukan penerapan metode Service Quality dalam rancang bangun kuesioner online untuk mengetahui tingkat kepuasan mahasiswa terhadap sarana dan prasaran di Laboratorium Informatika Teori dan Pemograman Dasar dan aplikasi mampu melakukan pengolahan data kuesioner lalu mencetak hasil perhitungannya [9].

Penelitian selanjutnya oleh Hidayat, melakukan pengukuran tingkat kepuasan pengguna layanan sebuah laboratorium. Metode dalam mengukur tingkat kepuasan adalah Service Quality, Customer Satisfaction Index (CSI) dan Importance Performance Analysis (IPA). Metode Service Quality digunakan untuk menilai ketimpangan antara harapan dengan kenyataan layanan yang didapat, untuk melihat kepuasan secara keseluruhan digunakan metode CSI dan menghubungkan 
antara kepentingan dan performa digunakan metode IPA. Teknik pengumpulan data yang digunakan adalah kuesioner yang sebelum memasuki tahap penilaian CSI, dilakukan uji validitas dan uji reabilitas pada kuesioner. Hasil yang didapatkan adalah kualitas layanan laboratorium yang kurang puas, hasil kinerja layanan dengan menggunakan CSI adalah cukup puas dengan layanan yang didapatkan dan laboratorium harus melakukan peningkatan pada fasilitas, ketepatan waktu, dan layanan serta lebih memerhatikan prioritas pengguna dari hasil yang diberikan dengan menggunakan metode IPA [10].

Penelitian selanjutnya oleh Rachmawati, melakukan pengukuran kepuasan pada suatu unit pembangkit. Penelitian tersebut membahas seberapa besar kepuasan layanan yang diberikan oleh pelanggan pada layanan. Metode analisis data yang dilakukan pada penelitian tersebut adalah mengidentifikasi variabel dan merancang kuesioner dengan responden berjumlah 48 orang yang terdiri dari pelanggan. Indikator kuesioner yang digunakan juga merupakan atribut pada setiap dimensi Service Quality dengan skala peniliaian yang digunakan adalah skala likert 7 poin. Setelah mendapatkan pengumpulan data kemudian pengolahan data pertama dilakukan uji validitas dan uji reabilitas, yang selanjutnya dianalisis statistika deskriptif guna mengetahui karakteristik pelanggan dengan menggunakan diagram batang dan crosstab. Selanjutnya melakukan analisis kesenjangan dengan menggunakan metode Top Two Boxes dan dilanjutkan mengidentifikasi tingkat harapan dan persepsi pada diagram kartesius. Hasil dari penelitian tersebut adalah terdapat faktorfaktor yang lebih dibenahi yang berkaitan dengan aspek kepuasan layanan. Salah satu faktor yang harus dibenahi adalah faktor kinerja dan fasilitas pendikung [11].

Penelitian selanjutnya yaitu menganalisis tingkat kepuasan dalam layanan perbankan syariah yang dilakukan oleh Cahyani. Teknik analisis yang dilakukan dalam penelitian tersebut adalah dengan menggunakan analisis lajur yang memiliki variabel eksogenus berupa kepuasan nasabah terhadap kualitas layanan bank. Metode pengumpulan data menggunakan kuesioner dengan responden nasabah bank syariah yang menggunakan metode purposive sampling dan convenience sampling. Penelitian ini menggunakan adaptasi model CARTER yang didasarkan pada dimensi Service Quality. Berdasarkan analisis tersebut, salah satu dimensi kualitas pada model CARTER memberi pengaruh penting pada tingkat mutu layanan dan kepuasan. Jadi, mutu layanan dan kepuasan nasabah sudah memiliki pengaruh yang baik dan sesuai dengan harapan nasabah [12].

Penelitian selanjutnya oleh Alaan, melakukan analisis terhadap kepuasan pelanggan dengan menggunakan Service Quality pada sebuah hotel di wilayah Bandung yang memaparkan tentang dampak kualitas layanan pada kepuasan pelanggan dan relevan terhadap industri perhotelan. Metode Service Quality digunakan untuk menguji pada dimensi yang berpengaruh terhadap kepuasan pelanggan. Metode pengumpulan data yang digunakan berupa kuesioner dengan teknik skala likert yang respondennya adalah pelanggan dengan metode purposive sampling. Kuesioner yang telah direspon selanjutnya diuji validitas dan reabilitasnya serta dilanjutkan dengan pengujian regresi secara simultas dan parsial. Hasil dari analisa tersebut mendapatkan bahwa kepuasan pelanggan dipengaruhi oleh servqual dengan nilai 35,80\%. Dimensi fakta nyata dan empati memiliki pengaruh pada kepuasan pelanggan dan dimensi keterampilan, daya tanggap dan jaminan tidak memiliki pengaruh terhadap kepuasan pelanggan [13].

Penelitian yang dilakukan oleh Novel, mengukur tingkat kepuasan layanan jasa dengan menggunakan dua metode yakni service performance dan CSI yang berpengaruh pada pentingnya kepuasan pelayanan jasa terhadap pasien terhadap di Puskesmas. Metode penelitian yang digunakan adalah Service Performance untuk mendapatkan tingkat kepuasan pelanggan, IPA digunakan untuk mendapatkan prioritas perbaikan hubungan antara tingkat kinerja dengan harapan pasien dalam diagram kartesius dan CSI digunakan untuk mengetahui tingkat kepuasan pasien yang berdasarkan kriteria nilai. Metode pengumpulan data yang digunakan adalah berupa kuesioner tertutup berdasarkan setiap karakter jasa dengan metode sampel Bernoulli dengan responden menggunakan purposive sampling. Data kemudian diolah dengan menggunakan Service Performance untuk mendapatkan ratarata tingkat harapan dan kinerja, lalu dipetakan hubungan antara harapan pasien dan kinerja dari tenaga kesehatan dengan IPA dan terakhir CSI untuk mengetahui tingkat kepuasan pasien dengan kriteria nilai. Berdasarkan hasil penelitian tersebut didapatkan bahwa CSI memiliki peringkat yang baik dan berada pada peringkat puas pada layanan yang diberikan di Puskesmas [14].

Penelitian selanjutnya oleh Yola, menganalisis kepuasan layanan dengan menggunakan IPA dan harga produk pada pelanggan. Hal tersebut dilakukan untuk dapat mempertahankan pelanggan agar terus dapat melakukan transaksi pada sebuah perusahaan retail. Proses pengumpulan data dilakukan dengan menggunakan kuesioner yang akan diuji validitas dan reabilitasnya setelah mendapatkan responden, setelah kuesioner dinyatakan valid dan reliabel maka dapat dilanjutkan dengan menggunakan metode IPA. Metode IPA digunakan untuk mengidentifikasi atribut kinerja dan harapan pada sebuah diagram kartesius, IPA juga dapat menentukan urutan prioritas layanan yang diukur dengan tingkat kesesuaian guna mendapatkan prioritas perbaikan layanan. Hasil dari penelitian tersebut mendapatkan bahwa perlunya meningkatkan pelayanan baik berupa fasilitas dan layanan jasa yang ada pada perusahaan retail. Jadi, metode IPA sangat membantu dalam menentukan layanan yang memiliki prioritas perbaikan dan mengidentifikasi atribut layanan yang masih kurang memuaskan pelanggan [15].

Penelitian selanjutnya oleh Suharyanta, mengukur tingkat kualitas pelayanan jasa di salah satu departemen layanan di rumah sakit. Penelitian yang bertujuan untuk meningkatkan pelayanan kesehatan agar terus dijaga kualitas pelayanannya menggunakan metode Service Quality Model Fuzzy. Penelitian tersebut menggunakan kuesioner sebagai teknik pengumpulan data dengan sampel pasien atau keluarga pasien yang pernah mendapatkan pelayanan pada departemen radiologi. Pengolahan data pertama dilakukan dengan mengintegrasikan Service Quality dengan fuzzy, kemudian dilanjutkan dengan 
fuzzyfikasi dengan pembentukan triangular fuzzy number nilai harapan dan kinerja, dan dilanjutkan defuzzyfikasi guna mendapatkan nilai tunggal yang representatif. Hasil dari penelitian tersebut, dimensi yang memiliki nilai gap tertinggi ada pada dimensi tangibles dan ruang radiologi yang perlu adanya perbaikan dalam peningkatan kualitas layanan serta secara keseluruhan menunjukan nilai negatif yang dimana harapan pasien tidak sesuai dengan kenyataan layanan di rumah sakit [16].

Penelitian selanjutnya oleh Siregar, mengukur dan mengevaluasi customer satisfaction terhadap layanan akses point pada perusahaan BUMN. Penelitian ini bertujuan untuk mengetahui faktor yang menyebabkan terjadinya kenaikan keluhan pelanggan wifi.id. Parameter keluhan juga menjadi fokus dalam penelitian tersebut agar dapat melakukan pembenahan baik secara fasilitas fisik ataupun fasilitas penunjang seperti layanan pada wifi.id. Metode Service Quality digunakan untuk mengukur persepsi pada kenyataan layanan yang didapatkan dan harapan layanan yang diinginakan. Instrumen pada penelitian tersebut menggunakan kuesioner dengan skala likert lima poin yang respondennya adalah pengguna wifi.id. Kuesioner yang sudah mendapatkan responden selanjutnya dilakukan uji validitas dan reabilitas, dan dilanjutkan dengan melakukan pengolahan menggunakan Service Quality untuk mendapatkan hasil kesenjangan antara harapan pelanggan dengan kinerja layanan yang diberikan. Hasil dari penelitian tersebut mendapatkan rata-rata pelanggan wifi.id menilai pelayanan yang diberikan belum puas terhadap dimensi kualitas dan ekspektasi pelanggan terhadap kelima dimensi ServQual adalah penting bagi pelanggan [17].

Penelitian selanjutnya oleh Adi, melakukan evaluasi kinerja Halte Bus dari aspek teknis dan pelayanan yang berdasarkan tipe halte near side, mid block dan far side. Kualitas pelayanan dibagi menjadi dua yakni pada aspek pelayanan di dalam bus dan pelayanan di luar bus. Pada pelayanan di luar bus, halte menjadi sarana penunjang yang baik dan meningkatkan pengalaman perjalanan bagi penumpang. Hasil dari penilaian kinerja pelayanan masih kurang baik yang disebabkan oleh kurang tepat waktu dari kedatangan Bus Trans Jogja dan waktu tunggu trayek Trans Jogja memakan waktu yang lama. Kinerja pelayanan yang baik didapatkan pada waktu muat penumpang dan waktu pengosongan yang singkat. Berdasarkan analisis dimensi Service Quality, dimensi kehandalan dan bukti fisik masih perlu untuk ditingkatkan lagi begitu pula pada atribut pelayanan yang memerlukan tindakan perbaikan oleh operator Trans Jogja [18].

Penelitian selanjutnya oleh Linggani, melakukan pengukuran tingkat kepuasan pelanggan Indihome di wilayah Bandung Barat. Indihome merupakan layanan provider internet dari PT. Telekomunikai Indonesia dimana pada penelitian tersebut bertujuan untuk mencari kebutuhan pelanggan yang dapat tingkatkan lagi. Untuk mencari kebutuhan pelanggan yang harus ditingkatkan digukan metode Service Quality agar dapat melihat perbedaan antara harapan dan kenyataan atau fakta layanan yang diterima oleh pengguna. Untuk mengetahui besaran pengaruh setiap variabel dengan tingkat kepuasan digunakan metode Kano. Penelitian tersebut menggunakan instrumen kuesioner pada setiap metode Service Quality dan model Kano yang akan menghasilkan nilai kepuasan pelanggan guna mengetahui atribut yang harus ditingkatkan pada metode Service Quality dan mengetahui klasifikasi atribut berdasarkan kategori Kano pada model Kano, lalu dilakukan integrasi antara hasil mode kano dengan metode Service Quality. Kombinasi antara servqual dan model Kano mendapatkan 26 variabel kebutuhan layanan provider internet yang mana 15 variabel diantaranya merupakan kebutuhan pelanggan yang harus ditingkatkan [19].

Penelitian selanjutnya oleh Larasati, melakukan pengukuran kepuasan terhadap kualitas pelayanan pada Osiris Coffee di Kota Bandung. Persaingan yang semakin ketat membuat perusahaan harus membuat pelanggan puas terhadap kualitas pelayanan. Pada penelitian tersebut bertujuan untuk melakukan analisa kualitas layanan terhadap kepuasan pelanggan dengan menggunakan metode servqual. Pengumpulan data yang digunakan pada penelitian tersebut menggunakan kuesioner dengan skala likert dan responden penelitian tersebut merupakan pelanggan dari Osiris Coffe. Pengolahan data dilakukan dengan menggunakan Service Quality untuk mencari kesenjangan antara harapan pelanggan dengan kinerja yang diberikan oleh Osiris Coffe. Hasil penelitian tersebut, mendapatkan hasil berupa kepuasan pelanggan pada coffee shop perlu ditingkatkan pada pelayanan ke pelanggan dan tepat waktu dalam melayani pelanggan [20].

Penelitian selanjutnya oleh Lubis, melakukan pengukuran kepuasan pelanggan terhadap perusahaan ekspedisi pengiriman logistik. Penelitian tersebut bertujuan guna memperoleh kategori faktor utama dalam pelayanan dan korespondensi antara kualitas layanan terhadap harapan pelanggan. Penggunaan metode dalam penelitian terebut adalah servqual dan Structural Equation Modelling (SEM) dimana Service Quality melakukan pengukuran perbedaaan antara harapan konsumen sesuai dengan kinerja dan penilaian mengenai kinerja aktual pada lima dimensi Service Quality. Metode pengumpulan data yang digunakan pada penelitian tersebut adalah kuesioner yang dilanjutkan dengan menentukan faktor kriteria kepuasan berdasarkan dimensi Service Quality dan pendekatan SEM melakukan pengukuran dengan menggunakan Cinfirmatory Factor Analysis (CFA). Hasil yang didapatkan adalah dimensi tangible dan responsiveness yang mempengaruhi kepuasan pelanggan serta perlunya peningkatan dan inovasi yang dapat dilakukan pada kondisi gedung, penataan ruangan dan penataan faktor berdasarkan dimensi ServQual lainnya [21].

Penelitian selanjutnya oleh Prananda, melakukan pengukuran dan evaluasi dalam peningkatan kualitas pelayanan terhadap pelanggan Hotel di Yogyakarta. Servqual digunakan untuk mengukur kualitas layanan yang akan dibahas pada setiap dimensi-dimensi pada Service Quality. Metode pengumpulan data yang digunakan adalah kuesioner dengan skala likert lima poin dan responden yang merupakan pelanggan hotel. Proses pengolahan data pertama adalah melakukan uji validitas dan reabilitas pada hasil kuesioner yang telah dijawab oleh responden dan selanjutnya melakukan pengolahan data dengan metode Service Quality baik pada 
setiap atribut pernyataan dan berdasarkan dimensi dari Service Quality. Hasil analisis yang diperoleh dimana kualitas pelayanan pada hotel mendapatkan nilai cukup baik dan perlu adanya peningkatan pelayanan agar mendapatkan kualita pelayanan yang meningkat. Sarana dan prasarana akan menjadi fokus pihak pengelola hotel agar dapat memenuhi tingkat kepuasan pelanggan hotel [22].

Penelitian selanjutnya yang dilakukan oleh Saputri, melakukan evaluasi kepuasan layanan pada sebuah aplikasi. Integrasi servqual dan webqual digunakan untuk melakukan pengukuran kepuasaan pengguna terhadap respon cepat tanggap layanan aplikasi. Untuk mengetahui tingkat kepuasan menggunakan metode Servqual yang berdasarkan dimensidimensi yang ada sedangkan webqual digunakan untuk mengindentifikasi situs web yang berdasar pada 3 atribut yakni kegunaan, kualitas informasi dan kualitas layanan [23]. Hasil memperolehkan bahwa pada aspek kegunaan menghasilkan nilai baik dan nilai puas pada layanan aplikasi MyIndihome dan harus perlu ditingkatkan serta perbaikan pada dimensi empati [24].

Penelitian selanjutnya oleh Syarifudin, melakukan pengukuran kualitas alumni pada kepuasan pelanggan. Akreditasi C yang dimiliki oleh Program Studi Teknik Industri membuat perlunya adanya peningkatan kualitas lulusan dari program studi. Metode servqual digunakan pada penelitian ini untuk mengetahui setiap faktor prioritas pada evaluasi layanan yang harus diawasi agar dapat mengetahui kepuasan pelanggan. Teknik pengumpulan data yang digunakan adalah kuesioner dengan responden adalah alumni teknik industri Universitas Banten Jaya lulusan tahun 2017. Proses pengolahan data kuesioner selanjutnya dilakukan dengan menguji validitas dan reabilitas kuesioner untuk mengetahui kuesioner tersebut valid dan reliabel. Selanjutnya hasil kuesioner diolah dengan menggunakan Service Quality untuk mendapatkan kesenjangan antara harapan alumni dengan kinerja pengajaran dosen yang diberikan. Kesimpulan yang didapatkan pada penelitian ini adalah tingkat kepuaan pengguna masih dinyatakan belum puas dan jajaran universitas perlu mengambil tindakan dengan cara memperbaiki sistem internal [25].

Penelitian selanjutnya oleh Yuniar, melakukan pengukuran dan evaluasi terhadap kualitas layanan ekspedisi. Penelitian tersebut dilakukan untuk menilai kualitas layanan dan jasa pengiriman barang. Metode Service Quality digunakan untuk mengukur kualitas agar mampu memberi solusi atas komplain pelanggan dan memajukan perusahaan dalam berkompetisi. Teknik pengumpulan data yang digunakan adalah kuesioner dengan skala likert dan responden pada penelitian tersebut merupakan pelanggan ekspedisi. Pengujian validitas dan reabilitas dilakukan setelah mendapatkan hasil kuesioner yang diberikan oleh responden dan dilanjutkan dengan pengolahan data menggunakan Service Quality untuk mengetahui kesenjangan antara harapan pelanggan dengan kinerja yang diberikan oleh ekspedisi. Hasil penelitian tersebut mendapat perolehan yang tidak puasnya pelanggan pada layanan yang diberikan pada atribut harapan pelanggan dan kualitas jasa yang diberikan [26].
Penelitian selanjutnya oleh Nurfitriyah, dalam penenilitannya melakukan pengukuran kualitas layanan peserta di Balai Diklat Keagamaan Semarang. Penelitian tersebut dilakukan untuk mencari kesenjangan harapan dengan kenyataan layanan yang diberikan oleh panitia kepada peserta dan mengukur kualitas layanan menggunakan metode zone of tolerance dan Service Quality. Pengambilan data pada penelitian ini menggunakan kuesioner dengan menggunakan skala likert dan responden yang merupakan peserta diklat yang berjumlah 140 orang. Teknik sampel yang digunakan adalah stratified proportional samping sehingga sampel pada penelitian ini didapatkan dengan jumlah 30 orang. Metode pengolahan data yang digunakan pertama adalah Service Quality untuk mendapatkan kesenjangan harapan peserta dengan kinerja layanan yang diberikan lalu dilanjutkan dengan Zone of Tolerance yang mengukur kualitas pelayanan yang memetakan pada variasi pelayanan yang masih bisa diterima oleh peserta diklat. Kriteria dari ZoT dibagi menjadi dua yakni adequate service level berupa tingkat pelayanan minimum yang dinilai peserta masih bisa diterima dan desired service level berupa tingkat pelayanan yang diharapkan bisa diterima oleh peserta. Penelitian ini mendapatkan hasil belum memuaskan peserta diklat dan nilai yang didapatkan dari metode Zone of Telorance berupa 9 atribut layanan yang ditoleransi oleh peserta dari sebanyak 15 atribut layanan yang terdapat pada metode zone of tolerance. Sehingga 9 atribut layanan tersebut harus lebih diperhatikan lagi untuk meningkatkan layanan yang diberikan kepada peserta diklat [27].

Penelitian selanjutnya oleh Lukita, melakukan pengukuran dan evaluasi kualitas layanan jasa di institusi perguruan tinggi. Penelitian tersebut bertujuan untuk menilai kualitas dan kinerja layanan jasa. Penelitian tersebut menganalisis tingkat kepuasan mahasiswa/mahasiswi dengan beberapa tahap pengujian dan menganalisis kinerja institusi perguruan tingga. Integrasi dari IPA dan servqual digunakan dalam penelitian ini untuk melihat perbandingan kinerja jasa dan melihat tingkat antara keseuaian harapan dan kinerja jasa. Berdasarkan hasil penelitian tersebut didapatkan bahwa layanan pada institusi pendidikan tinggi memiliki kategori amat baik dan ada beberapa hal yang perlu untuk ditingkatkan lagi [28].

Penelitian selanjutnya oleh Monika, melakukan penelitian dalam mengukur dan mengevaluasi kualitas layanan di Warung Ipang Surabaya. Pengukuran dilakukan untuk mengetahui kekurangan warung makan dan kebutuhan pelanggan serta komentar pelanggan dibandingkan dengan rumah makan lainnya. Metode yang digunakan pada panelitian tersebut adalah integrasi antara model Kano, servqual dan quality function deployment yang menghasilkan nilai terbaik pada atribut tata letak ruangan dan nilai terburuk terdapat pada variasi menu serta melakukan perbaikan pada fasilitas rumah makan dan inovasi menu baru [29].

Penelitian selanjutnya oleh Akbar, melakukan analisis kualitas layanan pembayaran samsat kendaraan bermotor. Sering terjadinya antrian yang ramai pada pelayanan pembayaran yang disebabkan oleh sumber daya manusia yang kurang mumpuni maka pada penelitian tersebut dilakukan pengukuran kualitas layanan dengan mengintegrasikan antara 
metode servqual dengan model Kano yang dapat mengetahui serta meningkatkan kualitas pelayanan di sebuah organisasi. Hasil yang diperoleh dari penelitian tersebut ditemukan bahwa tingkat kepuasan sebesar 0,86 yang dikategorikan baik dan perlunya peningkatan pada fasilitas layanan untuk mendapatkan perolehan nilai yang maksimal [30].

Penelitian selanjutnya oleh Hamidani, membuat aplikasi tentang penilaian kualitas layanan yang terdapat pada Perpustakaan di sekolah kejuruan. Belum adanya sebuah sistem pengukuran kualitas pelayanan yang mampu memberitahu pihak sekolah pada pelayanan perusatakaan yang harus tingkatkan dan membutuhkan perbaikan menjadi permasalahan yang harus dipecahkan pada penelitian tersebut. Pembuatan sistem dilakukan agar dapat melakukan pengukuran kualitas layanan dengan menerapkan metode servqual dengan menjadikan kuesioner sebagai media pengukur kepuasan layanan perpustakaan. Hasil yang didapat pada pengembangan sistem tersebut adalah terdapat 2 atribut servqual yang memiliki nilai negatif yakni responsiveness dan assurance yang dimana hal tersebut dapat dijadikan prioritas untuk dievaluasi dan ditingkatkan lagi pelayanannya [31]

Penelitian selanjutnya oleh Rosdiana, melakukan pengukuran kualitas layanan di sebuah institusi pendidikan tinggi. Penurunan jumlah calon mahasiswa yang mendaftar membuat Prodi MMT-ITS perlu melakukan pengukuran kualitas pada pelayanannya. Integrasi antara metode Service Quality dengan IPA digunakan pada penelitian tersebut untuk mendapatkan faktor apa saja yang harus ditingkatkan. Metode pengumpulan data yang digunakan pada penelitian ini adalah kuesioner yang selanjutnya akan diuji validitas dan reabilitasnya. Selanjutnya proses pengolahan data yang digunakan adalah Service Quality untuk mengetahui kualitas layanan dengan cara memperoleh kesenjangan antara harapan pelanggan dengan persepsi pelanggan dan untuk mengetahui posisi layanan dari proses hasil Service Quality digunakan metode IPA untuk mendapatkan posisi layanan yang memiliki prioritas utama agar dapat diperbaiki atau ditingkatkan. Sehingga hasil yang didapat adalah perlunya untuk meningkatkan pada fasilitas publik, dan layanan internal institusi kepada mahasiswa agar dapat membuat mahasiswa mendapatkan pelayanan yang memuaskan [32].

Penelitian selanjutnya oleh Vanisa, melakukan pengukuran dan evaluasi pada kualitas layanan di rumah sakit. Pengukuran dilakukan untuk menilai kualitas pelayanan sudah memenuhi harapan dan keinginan pasien. Metode yang digunakan adalah servqual yang akan mengukur kesenjangan antara layanan yang diharapkan dengan layanan yang diterima oleh pasien dan IPA untuk mengetahui layanan prioritas yang harus segera ditingkatkan. Metode pengumpulan data yang digunakan adalah kuesioner dengan total responden berjumlah 30 orang yang dilanjutkan dengan uji validitas dan reabilitas instrumen penelitian. Proses pengolahan data dilakukan dengan metode Service Quality untuk mengukur tingkat kepuasan pelanggan yang membandingkan harapan pelanggan dengan persepsi pelanggan. Metode IPA digunakan untuk memetakan layananlayanan rumah sakit yang segera diperbaiki atau ditingkatkan. Dari penelitian tersebut didapatkan hasil keseluruhan pada metode Service Quality berupa kesenjangan negatif yang artinya kualitas layanan rumah sakit masih rendah dan pelanggan belum puas terhadap layanan tersebut dan terdapat 6 atribut layanan yang harus menjadi prioritas utama bagi rumah sakit untuk dilakukan perbaikan [33].

Dari pembahasan penelitian yang sudah di-review, didapatkan penelitian yang memberikan nilai pengukuran yang baik dan terdapat juga penelitian yang memberikan nilai pengukuran yang rendah atau memberikan evaluasi terhadap atribut-atribut dalam Service Quality Model yang harus ditingkatkan kembali. Penerapan metode tersebut memberikan penilaian berupa nilai sesuai dari persepsi dan harapan pengguna. Pengukuran kualitas layanan atau kinerja dalam metode tersebut berpedoman pada skala nilai untuk menilai kesenjangan antara kenyataan dengan harapan pengguna dan adanya gap antara kedua nilai tersebut dalam setiap dimensi servqual.

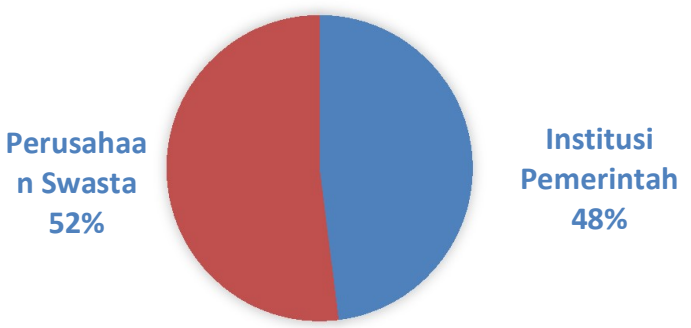

Gambar 2: Presentase organisasi yang dinilai

Gambar 2 menunjukan presentase kelompok organisasi yang dipilih dibagi menjadi 2 yakni dari swasta dan institusi pemerintah. Hal tersebut memiliki hubungan dengan penilaian layanan yang sering digunakan sebagai penunjang dalam hal kinerja maupun kualitas pelayanan barang/jasa. Perusahaan swasta memiliki presentase yang besar dikarenakan banyaknya layanan yang sering ditinjau dan dikeluhkan oleh pengguna. Kualitas layanan pada institusi pemerintahan menjadi sangat penting dalam hal kinerja yang diberikan kepada pelanggan.

\section{Jumlah Penelitian dengan Service Quality Model di Indonesia}

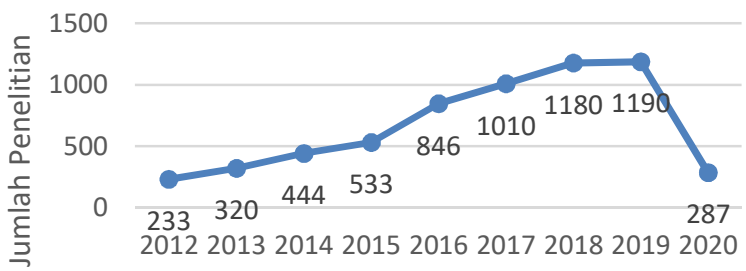

Tahun

Gambar 3: Jumlah Penelitian dengan Service Quality Model di Indonesia

Gambar 3 menunjukan perkembangan dari penelitian di Indonesia yang menggunakan metode Service Quality Model dalam melakukan pengukuran baik terhadap layanan dan kinerja dari Tahun 2012 sampai dengan Tahun 2020. Grafik 
menunjukan penggunaan servqual mengalami peningkatan setiap tahunnya dan pada sampai saat ini pengguna metode tersebut sudah mencapai sebanyak 287 penelitian di Indonesia. Hal tersebut dapat dijadikan dasar bahwa metode Service Quality Model masih sering digunakan dalam melakukan pengukPTuran tingkat kepuasan ataupun layanan pada sebuah organisasi dan sampai saat ini penggunaan metode tersebut masih akan mengalami peningkatan sampai di akhir Tahun 2020 .

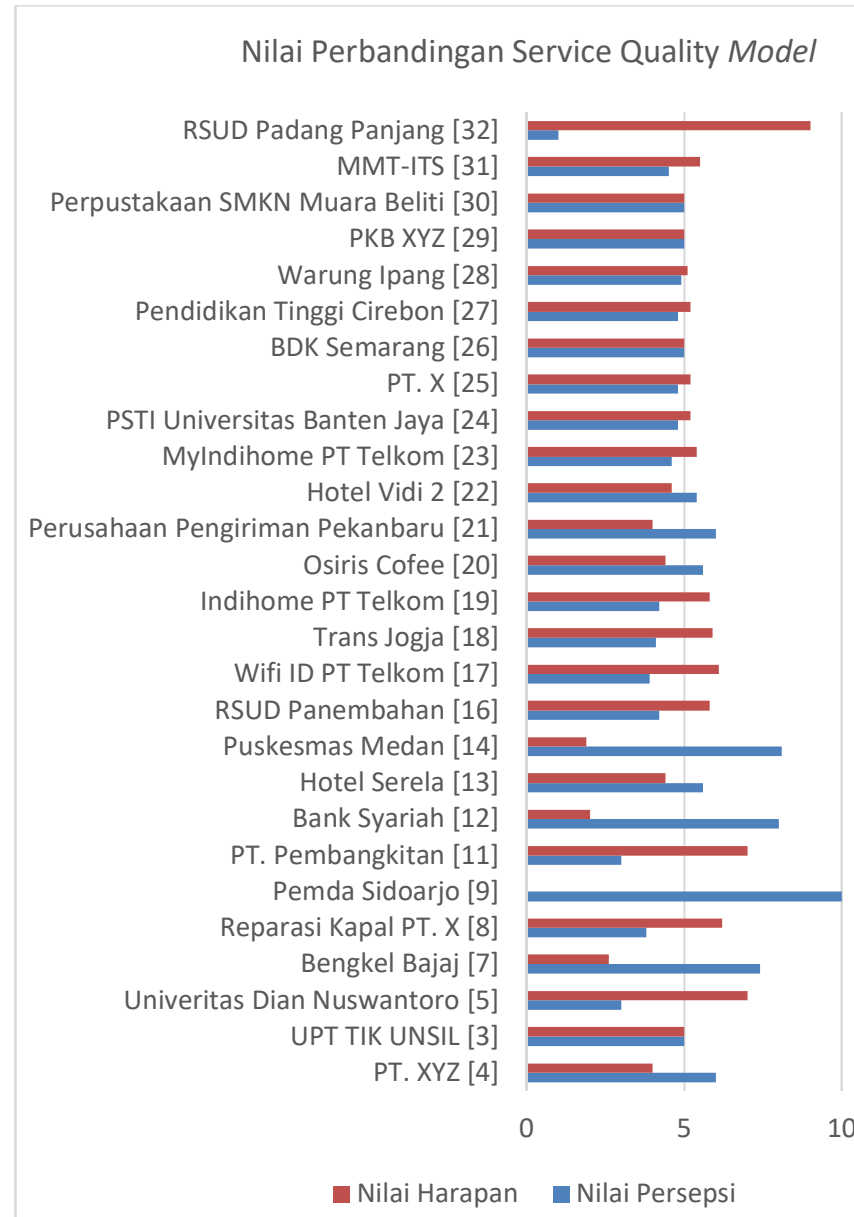

Gambar 4: Nilai Perbandingan Service Quality

Nilai perbandingan antara harapan dan persepsi seperti yang ditunjukan pada gambar 4 menunjukan bahwa rata-rata penelitian dengan menggunakan Service Quality memiliki nilai persepsi yang sudah cukup baik. Nilai dari harapan dari setiap organisasi adalah adanya atribut-atribut yang harus diperbaiki agar dapat memenuhi persepsi dari pengguna. Seperti yang ditunjukan pada penelitian di Pemerintah Daerah Kabupaten Sidoarjo memiliki nilai persepsi 10 dimana pada organisasi tersebut sudah merasa puas akan kinerja dan layanan yang diberikan kepada pengguna.

\section{B. Agenda Riset}

Berdasarkan kesimpulan penilaian dalam review tingkat kepuasan layanan produk/jasa menggunakan metode SQM maka penulis ingin melakukan penelitian mengenai tingkat kepuasan layanan pada sistem pengadaan barang dan jasa secara online atau e-Catalogue terhadap penyedia barang/jasa di Pemerintah Provinsi Bali. Analisis tingkat kepuaasan layanan e-Catalogue penyedia barang/jasa dilakukan dengan pengujian kepada pejabat pengguna layanan e-Catalogue dan staff pemerintah yang ikut serta dalam melakukan proses pengadaan barang/jasa melalui e-Catalogue. Dengan menggunakan metode SQM diharapkan mampu untuk memberi acuan bagi penyedia e-Catalogue dalam memperbaiki layanan yang diberikan baik berupa barang/jasa.

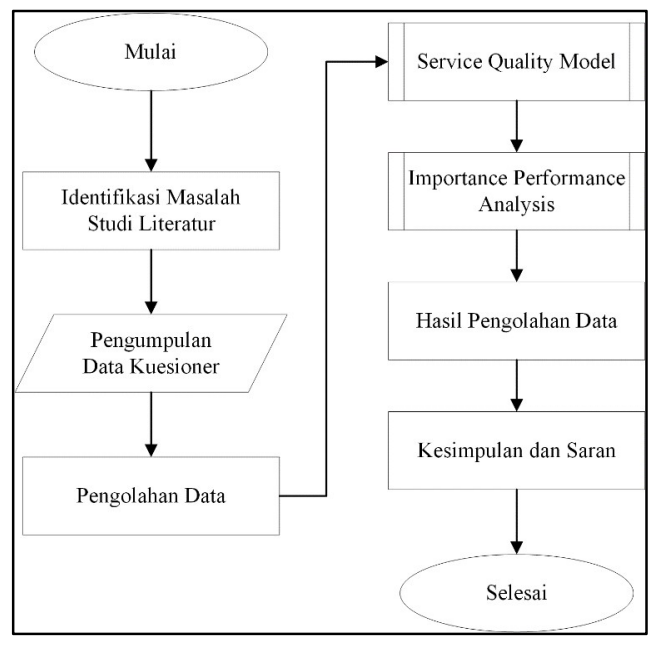

Gambar 5: Agenda Riset

Proses agenda riset penelitian yang akan dilakukan adalah melakukan studi literatur untuk memenuhi tinjauan pustaka agar sumber dari penelitian ini memiliki sumber-sumber yang kredibel dan dapat dipercaya. Proses pengumpulan data penelitian dilakukan sebagai informasi awal dalam proses penilaian tingkat kepuasan layanan agar hasilnya dapat maksimal dan instrumen penelitian yang akan dilakukan dengan menggunakan kuesioner skala likert tujuh poin. Data yang telah dikumpulkan kemudian akan diolah dengan menggunakan metode Service Quality di mana terdapat 5 dimensi yang akan dihitung agar dapat menentukan kualitas atribut layanan pada penyedia barang/jasa. Atribut-atribut tersebut dihitung berdasarkan tiap tiap dimensi yang ada dengan melihat gap yang timbul antara persepsi layanan secara nyata dan persepsi layanan berdasarkan harapan yang diharapkan oleh pengguna. Metode IPA digunakan untuk mengidentifikasi atribut-atribut layanan yang belum sesuai dengan harapan pelanggan dan memprioritaskan perbaikan pada layanan yang harus segera diperbaiki yang selanjutnya untuk dapat dianalisa sehingga kesimpulan pada penelitian yang akan dilakukan bisa disimpulkan. 


\section{KESIMPULAN}

Kesimpulan dari penelitian ini adalah metode Service Quality Model banyak digunakan dalam mengetahui tingkat kepuasan pengguna baik itu berupa layanan atau kinerja dalam sebuah organisasi. Dilihat dari hasil analisis dimana penelitian yang sudah ditinjau memiliki hasil yang sudah cukup baik dan terdapat sebuah layanan yang sudah memenuhi persepsi pengguna dan merasa puas dengan layanan yang diberikan. Jadi, metode Service Quality Model mampu untuk mengukur tingkat kepuasan baik itu berupa layanan dan kinerja serta mampu memberikan evaluasi terhadap organisasi yang sedang dinilai tingkat kepuasannya dan penggunaan metode tersebut lebih banyak digunakan pada perusahaan swasta sebesar 52\% dan institusi pemerintah sebesar $48 \%$.

\section{REFERENSI}

[1] Y. D. Putra, I. N. S. Kumara, N. W. S. Aryani dan I. B. A. Swamardika, "Literature Review Analisis Kinerja SDM Menggunakan Metode Behaviorally Anchored Rating Scale (BARS)," Majalah Ilmiah Teknologi Elektro, vol. 20, pp. 103-112, 2021.

[2] P. N. M. Weking, M. Sudarma dan K. O. Saputra, "User Experience Analysis Of "Ayooklik.Com" Online Store Using Use Questionnaire In Determining Product Segmentation," Majalah Ilmiah Teknik Elektro, vol. 19, pp. 19-25, 2020.

[3] M. Jazuli, D. Samanhudi dan H. , "Analisis Kualitas Pelayanan Dengan ServQual dan Importance Performance Analysis di PT. XYZ," Jurnal Manajemen Industri dan Teknologi, vol. 1, pp. 67-75, 2020.

[4] N. F. Kartika dan S. , "Implementasi Fuzzy-Service Quality Terhadap Tingkat Kepuasan Layanan Mahasiswa," Jurnal Ilmiah SISFOTENIKA, vol. 7, pp. 38-49, 2017.

[5] M. Anwar dan M. Azisan, "Analisis Tingkat Kepuasan Sistem Informasi Pencatatan dan Penagihan Biaya Rekning Air Pelanggan PDAM Menggunakan Metode End User Computing Satisfaction (EUCS)," Jurnal Teknologi Informasi dan Pendidikan, vol. 12, pp. 19-24, 2019.

[6] B. Harto, "Analisis Tingkat Kepuasan Pelanggan Dengan Pendekatan Fuzzy ServQual Dalam Upaya Peningkatan Kualitas Pelayanan," Jurnal TEKNOIF, vol. 3, pp. 20-30, 2015.

[7] A. Rahman dan H. Supomo, "Analisa Kepuasan Pelanggan pada Pekerjaan Reparasi Kapan dengan Metode Quality Function Deployment," Jurnal Teknik ITS, vol. 1, pp. 297-302, 2012.

[8] T. H. Wulandari, Y. K. Suprapto dan A. Affandi, "Analisis Tingkat Kepuasan Pelayanan E-Procurement Menggunakan Service Quality Model," JNTETI, vol. 8, pp. 241-250, 2019.

[9] R. N. Shofa, A. N. Rachman dan C. M. S. Ramdani, "Aplikasi Pengukuran Tingkat Kepuasan Mahasiswa Terhadap Sarana dan Prasarana Dengan Metode Service Quality Model di Laboratorium Informatika Teori dan Pemrograman Dasar Universitas Siliwangi," Jurnal Siliwangi, vol. 5, pp. 1-7, 2019.

[10] E. W. Hidayat, F. Maulana dan A. Rahmatulloh, "Analisis Service Quality Untuk Mengukur Tingkat Kepuasan Pengguna Layanan TIK di Universitas Siliwangi," Seminar Nasional Teknologi Informasi dan Multimedia, vol. 1, pp. 25-29, 2017.

[11] A. D. Rachmawati, I. Zain dan K. Yahya, "Analisis Statistik Kepuasan Pelanggan Terhadap Service Quality Unit Pembangkit PT. Pembangkitan Jawa-Bali," Jurnal Sains dan Seni ITS, vol. 1, pp. 329334, 2012.

[12] P. D. Cahyani, "Tingkat Kepuasan Nasabah Terhadap Kualitas Layanan Perbankan Syariah di Yogyakarta," Jurnal Bisnis dan Manajemen, vol. 6, pp. 151-162, 2016.

[13] Y. Alaan, "Pengaruh Service Quality (Tangible, Empathy, Reliability, Responsiveness dan Assurance) Terhadap Customer Satisfaction: Penelitian Pada Hotel Serela Bandung," Jurnal Manajemen, vol. 15, pp. 255-270, 2016.
[14] H. Novel dan H. L. Napitupulu, "Penilaian Tingkat Kepuasan Pasien Terhadap Pelayanan Jasa Puskesmas Medan Johor dengan Metode Servperf (Service Performance) dan Customer Satisfaction Index," $e$ Jurnal Teknik Industri FT USU, vol. 3, pp. 18-22, 2013.

[15] M. Yola dan D. Budianto, "Analisis Kepuasan Konsumen Terhadap Kualitas Pelayanan dan Harga Produk pada Supermarket dengan Menggunakan Metode Importance Performance Analysis (IPA)," Jurnal Optimasi SIstem Industri, vol. 12, pp. 301-309, 2013.

[16] D. Suharyanta dan Q. A'yunin, “Analisis Tingkat Kualitas Pelayanan Jasa Menggunakan Metode Service Quality (Servqual) Fuzzy di Instalasi Radiologi Rumah Sakit Umum Daerah (RSUD) Penambahan Senopati Bantul," Jurnal Fakultas Kesehatan Masyarakat, vol. 7, pp. 27-50, 2013.

[17] S. D. Siregar dan H. Suliantoro, "Meningkatkan Kepuasan Pelanggan Terhadap Kualitas Layanan Wifi ID dengan Metode Service Quality," Idustrial Engineering Online Journal, vol. 7, pp. 1-10, 2018.

[18] M. N. B. Adi, S. Priyanto dan S. Malkhamah, "Evaluasi Kinerja Halte Bus Dengan Metode Servqual (Studi Kasus Halte Trans Jogja Trayek 1A, 1B, 2A dan 2B)," Jurnal Teknisia, vol. 25, pp. 10-20, 2020.

[19] A. D. Linggani, H. Amani dan S. Wulandari, "Pengukuran Kepuasan Pelanggan Indihome Bandung Barat Menggunakan Integrasi Model Kano dan Metode Service Quality," e-Proceeding of Engineering, vol. 6, pp. 6548-6555, 2019

[20] P. Larasati dan S. Kritina, "Pengukuran Kualitas Pelayanan Terhadap Kepuasan Konsumen Menggunakan Metode Servqual Pada Osiris Coffee di Kota Bandung," e-Proceeding of Management, vol. 6, pp. 4556-4564, 2019.

[21] F. S. Lubis, A. P. Rahima, M. I. H. Umam dan M. Rizki, "Analisis Kepuasan Pelanggan Dengan Metode Servqual dan Pendekatan Structural Equation Modelling (SEM) Pada Perusahaan Jasa Pengiriman Barang di Wilayah Kota Pekanbaru," Jurnal Sains, Teknologi dan Industri, vol. 16, pp. 25-31, 2019.

[22] Y. Prananda, D. R. Lucitasari dan M. S. A. Khannan, "Penerapan Metode Service Quality (Servqual) Untuk Peningkatan Kualitas Pelayanan Pelanggan," Jurnal OPSI, vol. 12, pp. 1-11, 2019.

[23] I. K. C. Adi Putra, K. O. Saputra dan W. G. Ariastina, "Evaluasi Kualitas Dan Kepuasan Pengguna Website Imissu Dengan Penerapan Metode Webqual 4.0," Majalah Ilmiah Teknologi Elektro, vol. 18, pp. 259-266, 2019.

[24] E. Saputri dan D. Syamsuar, "Evaluasi Kepuasan Pengguna Layanan Aplikasi Mobile MyIndihome Berdasarkan Kombinasi Metode Servqual dan Metode Webqual," Jurnal TEKNO KOMPAK, vol. 14, pp. 27-32, 2020

[25] A. Syarifudin dan R. Hidayat, "Analisis Kualitas Lulusan Program Studi Teknik Industri Terhadap Kepuasan Pengguna Menggunakan Metode Servqual," Jurnal InTent, vol. 2, pp. 1-8, 2019.

[26] S. S. Yuniar, S. Arijanto dan G. P. Liansari, "Usulan Perbaikan Kualitas Pelayanan Jasa Pengiriman Paket Berdasarkan Hasil Pengukuran Menggunakan Metode Service QUality (Servqual) di PT. X," Jurnal Online Institut Teknologi Nasional, vol. 2, pp. 98-109, 2014.

[27] R. Nurfitriyah, "Kualitas Layanan Peserta Dengan Metode Servqual dan Zone Of Tolerance di Balai Diklat Keagamaan Semarang," Dialog, vol. 42, pp. 196-204, 2019.

[28] C. Lukita, S. Pranata dan K. Agustin, "Metode Servqual dan Importance Performance Analysis Untuk Analisa Kualitas Layanan Jasa Pendidikan Tinggi Pada Mahasiswa di Cirebon,” Jurnal DIGIT, vol. 9, pp. 167-177, 2019.

[29] S. Monika, "Analisis dan Usulan Perbaikan Kualitas Layanan Menggunakan Integrasi Metode Servqual, Model Kano, dan QFD di Warung Ipang Cabang Mayjend Sungkono Surabaya," Jurnal Ilmiah Mahasiswa Universitas Surabaya, vol. 1, pp. 1-19, 2012.

[30] N. B. Akbar dan Handoyo, "Analisis Kualitas Pelayanan Pembayaran Pajak Kendaraan Bermotor Dengan Metode Servqual dan Kano (Studi Kasus Wajib Pajak PKB di Kantor Bersama XYZ)," Jurnal Manajemen Industri dan Teknologi, vol. 1, pp. 57-68, 2020.

[31] S. Hamidani, V. Amalia dan J. Agustin, "Sistem Pengukuran Kualitas Layanan Pada Perpustakaan SMKN Muara Beliti Menggunakan Metode 
Serqual," Jurnal Ilmiah Binary STMIK Bina Nusantara Jaya, vol. 2, pp. $1-7,2020$.

[32] L. R. Noer, "Analisis Peningkatan Kualitas Pelayanan Mahasiswa Magister Manajemen Teknologi ITS Surabaya dengan Metode Servqual dan Importance Performance Analysis (IPA)," Journal of Research and Technologies, vol. 2, pp. 35-43, 2016.

[33] D. Vanisa, Firman dan H. A. Mesta, "Analisis Peningkatan Kualitas Pelayanan Pasien Menggunakan Metode Servqual dan Importance Performance Analysis (IPA)," Jurnal Kajian Manajemen dan Wirausaha, vol. 2, pp. 28-35, 2020.

[34] E. Dian, "Peran e-Catalogue Dalam Proses Pengadaan Elektronik," Jurnal Kalibrasi, vol. 13, pp. 1-7, 2015.

[35] A. Ningsih, A. Fudholi dan Sumarni, "Hubungan Penerapan Elektronik Katalog Terhadap Efisiensi Pengadaan dan Ketersediaan Obat," Jurnal Manajemen dan Pelayanan Farmasi, vol. 5, pp. 241-248, 2015.

[36] A. Pawitra, I. Kumara dan W. Ariastina, "Review Perkembangan PLTS di Provinsi Bali Menuju Target Kapasitas 108 MW Tahun 2025," Majalah Ilmiah Teknologi Elektro, vol. 19, pp. 181-188, 2020. 